\title{
Intracytoplasmic Sperm Injection (ICSI) in B6D2F1 and CB6F1 Strains Mice Using Cauda Epididymal Spermatozoa
}

\author{
B6D2F1 ve CB6F1 Irk Farelerde Kauda Epididimal Spermatozoa Kullanılarak \\ Intrastoplazmik Sperm Enjeksiyonu (ICSI)
}

\author{
Ali Cihan Taşkın ${ }^{(1)}$, Ahmet Kocabay² ${ }^{(1)}$, Nilhan Coşkun² (i) \\ 'Department of Laboratory Animal Science, Aziz Sancar Institute of Experimental Medicine, Istanbul University, Istanbul, Turkey \\ ${ }^{2}$ Translational Medicine Research Center, Experimental Animals Laboratory, Embryo Research Laboratory, Koç University, Istanbul, Turkey
}

ORCID ID: A.C.T. 0000-0003-3196-821X; A.K. 0000-0002-2365-7246; N.C. 0000-0001-5523-0813

Cite this article as: Taşkın AC, Kocabay A, Coşkun N. Intracytoplasmic sperm injection (ICSI) in B6D2F1 and CB6F1 strains mice using cauda epididymal spermatozoa. Experimed 2021; 11(3): 179-83.

\begin{abstract}
Objective: Reproductive biotechnology studies focus on the longterm storage of embryos (cryopreservation), embryo cultures, genome editing of embryos and embryo transfer. Micromanipulation techniques in reproduction biotechnologies have an important role, especially in studies investigating assisted reproductive technology in laboratory animals. The aim of the present study was to investigate the effect of epididymal spermatozoa injected to oocyte by intracytoplasmic sperm injection (ICSI) in different mice strains. In this study, we evaluated the in vitro development of post-ICSI derived embryos using cauda epididymal sperm.
\end{abstract}

Material and Method: Female mice (8-10 weeks) were superovulated using pregnant mare serum gonadotropin/human chorionic gonadotropin (PMSG/hCG) and $14 \mathrm{~h}$ post $\mathrm{hCG}$, the mice were sacrificed, and the oocytes were collected. Spermatozoa from the cauda epididymal of a 12-week-old were used on the same strain for ICSI and the in vitro developmental potential was evaluated. Finally, the embryos were cultured for 120 hours at $5 \% \mathrm{CO}_{2}$ with $37^{\circ} \mathrm{C}$.

Results: The results showed that the two-cell embryo of the B6D2F1 strain $(79.31 \%)$ was significantly higher than the CB6F1 $(56.26 \%)(p<0.05)$. While the blastocyst rate was comparable between both the B6D2F1 strain (68.75\%) and CB6F1 strain (69.57\%) ( $p>0.05$ ).

Conclusion: ICSI using cauda epididymal sperm is a suitable application for in vitro embryo development in B6D2F1 and CB6F1 strains. Finally, ICSI success of the B6D2F1 mice strains was found to be higher than CB6F1 mice strains.

Keywords: Mouse, oocyte, ICSI, development

\section{ÖZ}

Amaç: Üreme biyoteknolojisi alanındaki çalışmalar; embriyoların uzun süre saklanması (kriyoprezervasyon), embriyo kültürü, embriyoların genom düzenlenmesi araştırmaları ve embriyo transferi gibi konular üzerinde yoğunlaşmaktadır. Üreme biyoteknolojilerinde mikromanipülasyon teknikleri, özellikle laboratuvar hayvanlarında yardımcı üreme teknolojisinin araştıııldığı çalışmalarda önemli bir yere sahiptir. Bu çalışmanın amacı, farklı fare ırklarında intrastoplazmik sperm enjeksiyonu (ICSI) ile epididimal spermatozoanın oosite enjeksiyonunu araştırmaktır. Bu çalışmada, kauda epididimal fare spermi kullanılarak yapılan ICSI uygulaması sonrasında elde edilen embriyoların in vitro gelişimi değerlendirilmiştir.

Gereç ve Yöntem: Dişi fareler (8-10 hafta), gebe kısrak serum gonadotropini/insan koryonik gonadotropini (PMSG/hCG) kullanılarak süperovüle edilmiş, hCG'den 14 saat sonra fareler sakrifiye edilerek oositler toplanmıştır. 12 haftalık erkek farenin kauda epididiminden alınan spermatozoa, aynı ırk oositle ICSI için kullanılmış ve in vitro gelişim potansiyeli değerlendirilmiştir. Son olarak tüm embriyolar 120 saat süre ile $\% 5 \mathrm{CO}_{2}$ ve $37^{\circ} \mathrm{C}$ 'de kültüre edilmiştir.

Bulgular: Sonuçlar, B6D2F1 $(\% 79,31)$ ırkının 2 hücreli embriyo gelişiminin CB6F1 $(\% 56,26)$ ırklı farelerdeki 2 hücreli embriyo gelişiminden önemli ölçüde yüksek olduğunu göstermiştir $(p<0,05)$. Blastosist oranı B6D2F1 $(\% 68,75)$ ve CB6F1 $(\% 69,57)$ ırkları arasında karşılaştırılmıştır $(p>0,05)$.

Sonuç: B6D2F1 ve CB6F1 fare ırklarında, kauda epididimal sperma kullanılarak yapılan ICSI in vitro embriyo gelişimi için uygun bir yöntemdir. Sonuç olarak, B6D2F1 farelerde ICSI'nın başarısı, CB6F1 Irk farelere göre daha yüksektir.

Anahtar Kelimeler: Fare, oosit, ICSI, gelişim 


\section{INTRODUCTION}

Intracytoplasmic sperm injection (ICSI) is the name given to the method of injecting spermatozoa into the oocytes through microsurgical methods. It is a common approach in clinical practice in the treatment of infertility problems with various causes, and in the production of farm and laboratory animals (transgenic and low-reproductive strains) $(1,2)$. There is a need for a convenient and cost-effective method for long-term sperm preservation of transgenic mice (3).

It is well known that the genetic background of mouse strains affects morphological parameters of sperm (4-6) and in vitro produced embryo development (7). Most common mouse strains are used for developing new transgenic lines. And their embryo development results can be compared to the other strains (4-6). Furthermore, using different mouse strains in ICSI can affect embryo development (8-10).

The genetic characteristics of different mouse strains affect embryo development results in mouse embryo studies. Also, no research was found in literature about results of in vitro developments of ICSI between oocytes from CB6F1 mouse strain. The present study analyzes the in vitro development rates of embryos produced by the application of ICSI in comparison to the mouse strains of CB6F1 (C57BL/6J $\times$ Balb/c) and B6D2F1 (DBA2 x C57BL/6J).

\section{MATERIAL AND METHOD}

All mice experiments were approved by Koc University Local Ethics Committee for Animal Experiments (approval number: 2014-05). The animals were kept in Koc University, Animal Research Facility of Center for Translational Medicine (KUTTAM) under 12 hours light - 12 hours dark cycle, and a diet of commercial pellet food ad-libitum and automatic water containers were provided according to the Guide for the Care and Use of Laboratory Animals.

\section{Superovulation and Oocyte Collection}

10 IU of pregnant mare serum gonadotropin (Sigma G4877PMSG) was injected by intraperitoneal (IP) to the female mice between 17:00 and 18:00, and 48 hours later, $10 \mathrm{IU}$ of human chorionic gonadotropin (Organon-hCG) was injected by intraperitoneally between 17:00 and 18:00 hours. Fourteen hours after the hCG injection, female mice were sacrificed, and the oocytes were collected by rupturing the oviductal ampullae. The oocytes were washed in HEPES buffered human tubal fluid (HTF) medium with hyaluronidase, and then washed three times in a hepes buffered-M2 medium supplemented with 4 $\mathrm{mg} / \mathrm{ml}$ BSA (Sigma Catalog, No A-3311, Fraction V). The culture media containing the collected oocytes were kept in an incubator at $37^{\circ} \mathrm{C}$ and in $5 \% \mathrm{CO}_{2}$ for $30-60$ minutes until the ICSI was performed (10). $10 \mu \mathrm{l}$ of embryo culture drops were added to a petri dish and covered with mineral oil (Lifeguard-Life Global) in order to avoid the contamination, evaporation and to ensure integrity of the drops. The petri dishes were then placed in an incubator at $37^{\circ} \mathrm{C}$, in $5 \% \mathrm{CO}_{2}$ and humidity for gassing at least 2 hours prior to embryo collection.

\section{Preparation of Spermatozoa}

The male mice of each strain were sacrificed, cauda epididymis were removed and incubated in $500 \mu$ l embryo culture medium (LifeGlobal Media, LGGG-020) at $37^{\circ} \mathrm{C}, 5 \% \mathrm{CO}_{2}$ for 10 minutes. Then, $100 \mu \mathrm{l}$ was collected from the top of the tube and transferred to the cryotube. The spermatozoa were rapidly frozen in liquid nitrogen which lead to breakage of sperm tail and head $(11,12)$.

\section{Intracytoplasmic Sperm Injection (ICSI)}

After oocyte collection from the petri dish, a $10 \mathrm{~cm}$ petri dish cover was used, the area of which was divided into four sections. Fifteen $\mu \mathrm{l}$ drops were placed in the petri dish and covered with 7-8 $\mathrm{ml}$ of mineral oil (Figure 1), and $3 \mu$ lof frozen-thawed spermatozoa were placed in $\mathrm{M} 2+3 \%$ polyvinyl-pyrrolidone (PVP) drops. ICSI working plate prepared with small droplet of manipulation HEPES buffered HTF medium. The sperm was mixed with five volumes of a $10 \%$ solution of PVP $(\mathrm{v} / \mathrm{v})$ in HEPES buffered HTF medium. A droplet of piezo pipette prepared for washing in volumes of a $3 \%$ solution of PVP in HEPES buffered HTF medium. The spermatozoa were mixed using a manipulation pipette to ensure individual cell formation. ICSI started 16-18 hours after hCG injection and performed by using a Nikon Eclipse and an inverted microscope equipped with Eppendorf TransferMan/ Nk 2 micromanipulators. An Eppendorf CellTram Vario embryo holding pipette console and an Eppendorf embryo holding pipette with a $35^{\circ}$ angle, $15 \mu \mathrm{m}$ inner diameter and a $100 \mu \mathrm{m}$ outer diameter were mounted on the left micromanipulator. An Eppendorf CellTram Air embryo manipulation pipette console and an Eppendorf embryo ICSI piezo drill micropipette (Origio/ CooperSurgical, U.S.A, Piezo-6-25) with a $6^{\circ}$ angle, $6 \mu \mathrm{m}$ inner diameter and an $8 \mu \mathrm{m}$ outer diameter were mounted on the right micromanipulator. The spermatozoa were taken sequentially into the injection pipette (Figure 2A). The injection pipette was transferred into manipulation drops. Using a holding pipette (Optimas, reference code: OMH1202030) with loaded 2-3 $\mu \mathrm{l}$ mercury, the oocytes were fixed at the 6 or 12 o'clock position of the MII (Figure 2A). Using a piezo drill (Prime Tech PMM4G) injection pipette, a single-pulse piezo of $4 / 4$ (intensity/velocity) was made to puncture the zona pellucida of the oocyte (Figure $2 B, 2 C$ ). Minimum suction of cytoplasm was applied into the ICSI injection pipette (Figure 2D, 2E) and a single-pulse piezo of 2/1 (intensity/velocity) was applied to break the cytoplasm and inject the sperm to oocyte immediately (Figure 2F, 2G). The sperm injection into the cytoplasm was conducted at room temperature $\left(17-18^{\circ} \mathrm{C}\right)(11,12)$.

\section{Post-ICSI Embryo Culture}

The ICSI-treated oocytes were transferred into a culture medium, and the embryos were washed in at least three times and then incubated at $37^{\circ} \mathrm{C}$ and in $5 \% \mathrm{CO}_{2}$ for $96-120$ hours respectively. The two cell and blastocyst developments were evaluated on $2^{\text {th }}$ day and $5^{\text {th }}$ day, respectively.

\section{Statistical Assessment of Results}

IBM SPSS Statistics for Windows (Version 24.0. Armonk, NY: IBM Corp.) was used for the statistical assessment of the results with 


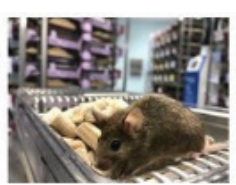

CB6F1

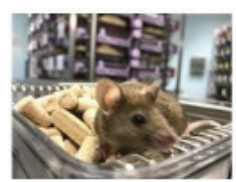

C57BL/6J X Balb/C

B6D2F1 DBA X C57BL/6J

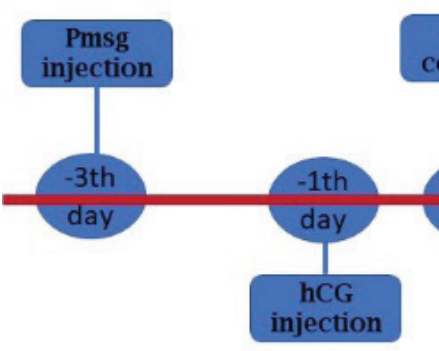

\section{Sperm} collection

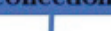

\section{Working plate} oj
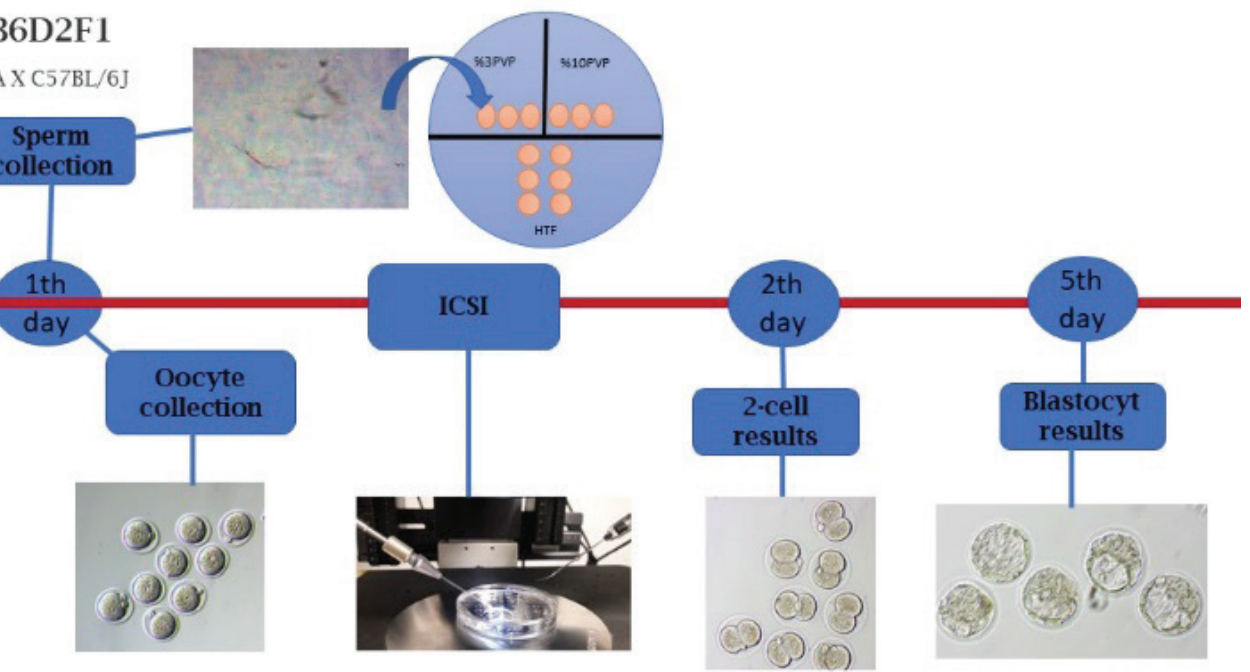

Figure 1. Schematic depicting the experimental timeline in mouse intrastoplasmic sperm injection (ICSI).

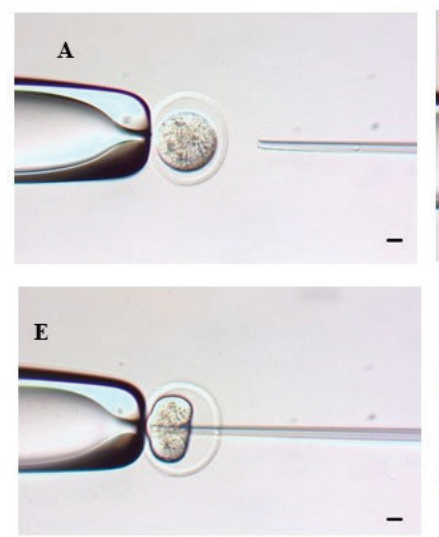

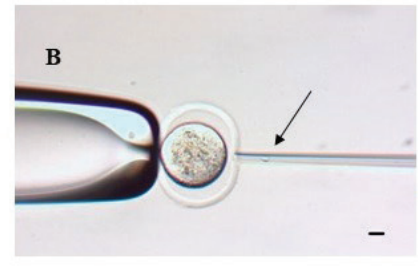

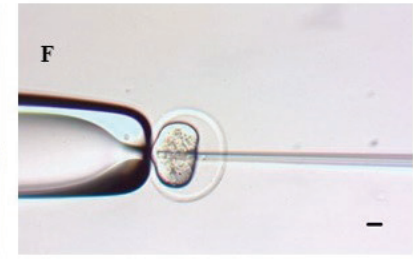

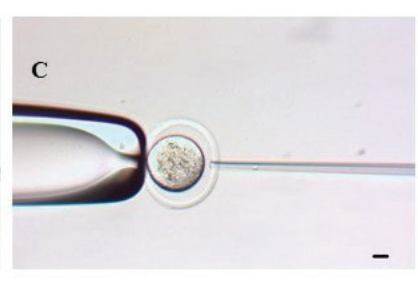

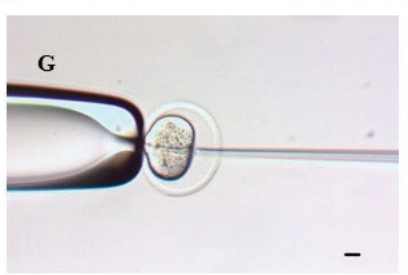

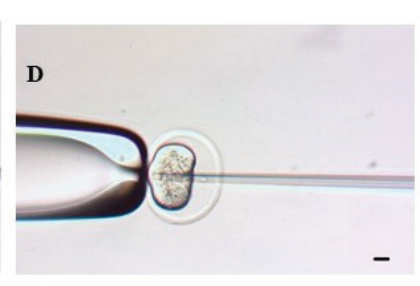

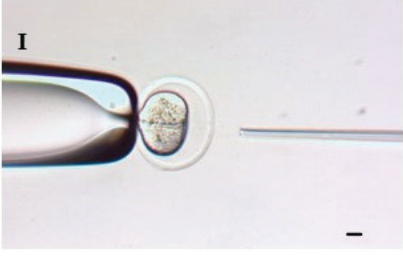

Figure 2. Piezo drill of ICSI on mouse oocyte. (A) The sperm was sucked into the injection pipette, (B) the arrow is sperm in injection pipette and zona pellucida aspirated by injection pipet, $(C)$ a single-pulse piezo was made to puncture the zona pellucida of the oocyte, $(D, E)$ aspiration of cytoplasm is applied into injection pipette and apply a single-pulse piezo to break to cytoplasm, (F) the sperm injected to oocyte, $(G, I)$ when withdrawing the ICSI pipette out of the sperm injected mouse oocyte (20X).

sufficient number of repetitions. ANOVA and Chi-square tests were used for the analysis of variance and differences between groups. The $p$-values $<0.05$ were considered statistically significant. All experiments were replicated three times.

\section{RESULTS}

According to development evaluations done after in vitro culture, the two cell development rates were $56.26 \%$ and $79.31 \%$, in CB6F1 and B6D2F1 strain groups, respectively $\mathrm{p}<0.05$, Table 1). The differences of two cell development were found significantly important between in CB6F1 and B6D2F1 strain groups $(p<0.05)$. The blastocyst development rates were $68.75 \%$ and $69.57 \%$, in CB6F1 and B6D2F1 strain groups, respectively (Table 1). The differences of blastocyst development were no found significantly between the CB6F1 and B6D2F1 strain groups ( $p>$ 0.05, Table 1). 
Ethics Committee Approval: All mice experiments were approved by Koc University Local Ethics Committee for Animal Experiments (approval number: 2014-05).

Peer-review: Externally peer-reviewed.

Author Contributions: Conception/Design of Study - A.C.T.; Materials A.K., N.C.; Data Collection - A.C.T.; Analysis and/or Interpretation - A.C.T., A.K., N.C.; Drafting Manuscript - A.C.T., A.K., N.C.; Final Approval and Accountability - A.C.T., A.K., N.C.

Conflict of Interest: The authors have no conflict of interest to declare.

Financial Disclosure: This research was supported by a grant from The Scientific and Technological Research Council of Turkey (TUBITAK, Grant Number: TOVAG 1140638).

Teşekkür: Bu çalışma, TC Kalkınma Bakanlığı tarafından desteklenen, Koç Üniversitesi Translasyonel Tıp Araştırma Merkezi (KUTTAM)'nin hizmet ve altyapısı kullanılarak yürütülmüştür. Yazının içeriğinden tümüyle yazarlar sorumludur ve Kalkınma Bakanlığı'nın resmi görüşünü yansıtmamaktadır.

Etik Komite Onayı: Tüm fare deneyleri Koç Üniversitesi Hayvan Deneyleri Yerel Etik Kurulu tarafından onaylanmıştır (onay numarası: 2014-05).

Yazar Katkıları: Çalışma Konsepti/Tasarımı - A.C.T.; Materyal: A.K., N.C.; Veri Toplama - A.C.T.; Veri Analizi/Yorumlama - A.C.T., A.K., N.C.; Yazma A.C.T., A.K., N.C.; Son Onay ve Sorumluluk - A.C.T., A.K., N.C.

Çıkar Çatışması: Yazarlar çıkar çatışması bildirmemişlerdir.

Finansal Destek: Bu araştırma, Türkiye Bilimsel ve Teknolojik Araştırma Kurumu (TÜBITAK, Proje Numarası: TOVAG 1140638) tarafından sağlanan proje ile desteklenmiştir.

\section{REFERENCES}

1. Andersen ML, Winter LM. Animal models in biological and biomedical research-experimental and ethical concerns. An Acad Bras Cienc 2019; 91. [CrossRef]

2. Yanagimachi R. Intracytoplasmic injection of spermatozoa and spermatogenic cells: its biology and applications in humans and animals. Reprod Biomed Online 2005; 10(2): 247-88. [CrossRef]

3. Li MW, Willis BJ, Griffey SM, Spearow JL, Lloyd KC K. Assessment of three generations of mice derived by ICSI using freeze-dried sperm. Zygote 2009; 17(3): 239-51. [CrossRef]

4. Songsasen N, Leibo SP. Cryopreservation of mouse spermatozoa II. Relationship between survival after cryopreservation and osmotic tolerance of spermatozoa from three strains of mice. Cryobiology 1997; 35: 255-69. [CrossRef]

5. Sztein JM, Farley JS, Mobraaten LE. In vitro fertilization with cryopreserved inbred mouse sperm. Biol Reprod 2000; 63: 1774-80. [CrossRef]
6. Nishizono H, Shioda M, Takeo T, Irie T, Nakagata N. Decrease of fertilizing ability of mouse spermatozoa after freezing and thawing is related to cellular injury. Biol of Reprod 2004; 71: 973-8. [CrossRef]

7. Dandekar PV, Glass RH. Development of mouse embryos in vitro is affected by strain and culture medium. Gamete Res 1978; 17 : 279-85. [CrossRef]

8. Ogonuki N, Mori M, Shinmen A, Inoue K, Mochida K, Ohta A, et al. The effect on intracytoplasmic sperm injection outcome of genotype, male germ cell stage and freeze-thawing in mice. PLoS One 2010; 5(6): e11062. [CrossRef]

9. Wakayama T, Perry AC, Zuccotti M, Johnson KR, Yanagimachi R. Full-term development of mice from enucleated oocytes injected with cumulus cell nuclei. Nature 1998; 394, 369-74. [CrossRef]

10. Taskin AC, Kocabay A, Gül S, Caglar-Erkal K. Comparison of parthenogenetic oocyte activation in different mouse strains on in vitro development rate and quality. Vet Hekim Der Derg 2021; 92(1): 42-8.

11. Wang $Y$, Yamauchi $Y$, Wang $Z$, Zheng $H$, Yanagimachi $R$, Ward $M A$, et al. Both Cauda and Caput Epididymal Sperm Are Capable of Supporting Full-Term Development in FVB and CD-1 Mice. Dev Cell 2020; 55(6): 675-6. [CrossRef]

12. Mallol A, Santaló J, Ibáñez E. Psammaplin a improves development and quality of somatic cell nuclear transfer mouse embryos. Cell Reprogram 2014;16(5): 392-406. [CrossRef]

13. Fernández-González R, Laguna R, Ramos-lbeas P, Pericuesta E, Alcalde-Lopez V, Perez-Cerezales $\mathrm{S}$, et al. Successful ICSI in Mice Using Caput Epididymal Spermatozoa. Front Cell Dev Biol 2019; 7: 346. [CrossRef]

14. Stein P and Schultz RM. ICSI in the mouse. Methods Enzymol 2010; 476: 251-62. [CrossRef]

15. Ohta $H$, Sakaide $Y$ and Wakayama T. Age and substrain-dependent sperm abnormalities in BALB/c mice and functional assessment of abnormal sperm by ICSI. Hum Reprod 2009; 24(4): 775-81. [CrossRef]

16. Ogonuki N, Mori M, Shinmen A, Inoue K, Mochida K, Ohta A, et al. The effect on intracytoplasmic sperm injection outcome of genotype, male germ cell stage and freeze-thawing in mice. PLoS One, 2010; 5(6): e11062. [CrossRef]

17. Kawase $Y$, Iwata T, Toyoda Y, Wakayama T, Yanagimachi R and Suzuki H. Comparison of intracytoplasmic sperm injection for inbred and hybrid mice. Mol Reprod Dev 2001; 60(1): 74-8. [CrossRef]

18. Fernández-González R, Laguna R, Ramos-lbeas P, Pericuesta E, Alcalde-Lopez V, Perez-Cerezales $S$, et al. Successful ICSI in Mice Using Caput Epididymal Spermatozoa. Front Cell Dev Biol 2019; 7: 346. [CrossRef]

19. Moreira PN, Giraldo P, Cozar P, Pozueta J, Jiménez A, Montoliu L, et al. Efficient generation of transgenic mice with intact yeast artificial chromosomes by intracytoplasmic sperm injection. Biol Reprod 2004; 71(6): 1943-7. [CrossRef] 